\title{
ПЕРСПЕКТИВЫ ПРОГРАММИРУЕМОЙ БИОМЕХАНИКИ В ВОСПРОИЗВЕДЕНИИ ОПОРНО-ДВИГАТЕЛЬНЫХ ФУНКЦИЙ БОЛЬНЫХ И ИНВАЛИДОВ
}

\author{
Ю. М. Барчина, О. А. Горбунов, Е. А. Осадчий \\ Киевская городская клиническая больница № 4
}

\begin{abstract}
Международный научно-учебный центр информационных технологий и систем НАН и МОН Украины
\end{abstract}

\section{Киевский национальный университет имени Тараса Шевченко}

\begin{abstract}
Анотація. В роботі показана перспектива спільного застосування вітчизняного пасивного керованого екзоскелетону (ЕКС) з програмованою біомеханікою і засобів м'язової електростимуляції для відновлення опорно-рухових функцій хворих і інвалідів.
\end{abstract}

Одним из приоритетных направлений оптимизации процесса двигательной реабилитации больных, перенесших инсульт и спинальную травму, является совместное применение различных реабилитационных технологий. Программируемая электростимуляция нейромышечного аппарата во время выполнения естественного движения, например ходьбы, является эффективным методом двигательной реабилитации и способом коррекции патологических двигательных стереотипов данной категории пациентов (А. С. Витензон, К. А. Петрушанская, 2003).

Однако в связи с тем что у значительной части пациентов имеются стойкие двигательные нарушения, которые ограничивают возможность применения электростимуляции в движении, перспективным является применение ее в сочетании с ЭКС.

Для биомеханики отечественного аппарата «Экзоскелетон» характерна реализация активного человекомашинного взаимодействия. Она достигается применением внешнего программируемого механического воздействия ЭКС на опорно-двигательный аппарат и костно-мышечную систему человека. Не менее важной является обратная управляющая функция со стороны супраспинальной центральной нервной системы (ЦНС) пользователя. Использование внешних приводов и средств компьютерного управления в аппаратах класса пассивный управляемый экзоскелетон концептуально должны быть второстепенными, как и задача уменьшения опорно-двигательной нагрузки. И не только потому, что механическое воздействие является наиболее доступным в реализации, естественным, эффективным, надежным и распространенным. Не случайно человечество до сих пор успешно использует мобильные и стационарные устройства (кровать, стул, велосипед и проч.) и еще долго не сможет от них отказаться. Потому что они успешно решают проблему опорно-двигательного отдыха и (или) тренировки, например, велосипед, костыль и другие. ЭКС с трансформируемыми свойствами является логическим продолжением развития такого класса устройств. Созданию гомологичных механически ориентированных ЭКС наконец стали уделять внимание и в развитых странах мира. Так, например, известна успешная попытка создания ЭКС такого класса студенческим конструкторским бюро при университете города Окинава. Хотя их успех связан в основном с использованием возможностей известного в механике эффекта рычага для увеличения размеров искусственного наружного скелета. Более существенным достижением можно считать сообщение о создании в Японии механических роботизированных протезов ног, которые без применения внешних энергоемких приводов обеспечивают шаговое перемещение человека. Особенно они эффективны при шаговом перемещении сверху вниз. Аналогичные технические решения используются и в отечественных ЭКС. Так, нами уже разработаны искусственные суставы, биомеханика которых позволяет использовать их в качестве управляемых шарнирных сочленений для протеза ноги. Исключительно с помощью механики, в том числе датчиков углового перемещения, они обеспечивают высокогомологичную функцию протеза. Это решение значительно проще, чем, например, применение искусственного интеллекта для роботизированных кибернетических протезов ряда известных фирм-разработчиков. Тем более, что проблемы целеуказания и пространственной ориентации все равно решаются ЦНС пользователя.

Приведем перечень основных опорно-двигательных функций многофункционального шарнирного со-

( Ю. М. Барчина, О. А. Горбунов, Е. А. Осадчий 
членения ЭКС, которые могут быть использованы в качестве альтернативных для нужд протезирования, например, в протезе коленного сустава:

- дозированное фрикционное сопротивление угловому перемещению рычагов при их изгибе и / или разгибе в интервалах от $0^{0}$ до $120^{\circ}$ в нужной плоскости движения сустава;

- свободное угловое перемещение рычагов при их изгибе (разгибе) в интервале от $0^{0}$ до $24^{0}$ с дискретностью $8^{0}\left(16^{0}\right)$ в нужной плоскости движения сустава;

- дозированное фрикционное сопротивление одностороннему угловому перемещению рычагов с дискретностью в $8^{0}\left(16^{0}\right)$ при изгибе (разгибе) в интервале от $8^{0}\left(24^{0}\right)$ до $120^{\circ}$ в нужной плоскости движения сустава;

- жесткое ступенчатое сопротивление одностороннему угловому перемещению рычагов с дискретностью в $8^{0}\left(16^{0}\right)$ при изгибе (разгибе) в интервале от $8^{0}\left(24^{0}\right)$ до $120^{0}$ в нужной плоскости движения сустава;

- ручная блокировка (разблокировка) с дискретностью в $8^{0}\left(16^{0}\right)$ фрикционного (жесткого) одностороннего углового перемещения рычагов при изгибе (разгибе) с дозированным усилием фиксации, в интервале от $8^{0}\left(24^{0}\right)$ до $120^{0}$ в нужной плоскости движения сустава;

- автоматизированная, в опорный момент локомоции, под действием дозированного усилия мышц (массы тела), блокировка (разблокировка) с дискретностью в $8^{0}\left(16^{0}\right)$ фрикционного (жесткого) одностороннего углового перемещения рычагов при изгибе (разгибе) с дозированным усилием сдерживания фиксации, в интервале от $8^{\circ}\left(24^{\circ}\right)$ до $120^{\circ}$ в нужной плоскости движения сустава.

Такие свойства ЭКС позволяют эффективно восстанавливать (усиливать) опорно-двигательные фун-

\section{Литература}

1. First experience in rehabilitation of patients with spinal board disorders with "Exoskeleton" device The International Conference of Traumatologists and Orthopaediecs of Azerbaijan devoted to the 60 th anniversary of the ScientificResearch Institute of Traumatology and Orthopaedics of the Azerbaijan Republic / Fishenko V.I., Osadchyy Y. O., Vovk N. N., Barchina U. M. - Baki. - Abstract Book. -25-26 may 2007. - P. 1.

2. Концепция построения и опыт медицинского применения аппарата “Экзоскелетон” / Е. А. Осадчий, А. Т. Сташ- кции пациента и проводить занятия по восстановлению локомоторных функций. Для усиления эффекта дополнительно проводилась миоэлектростимуляция в движении. Это позволяло формировать физиологичный паттерн нейромышечной активности не только на уровне спинальных локомоторных структур, но и на более высоких уровнях иерархии центральной нервной системы.

Сеансы восстановительной терапии проводились с использованием клинического варианта ЭКС и электростимулятора Миоритм 186с синхронизированных с моментом отрыва стопы от поверхности. Нейрофизиологическая сущность такого метода заключается в точном временном соответствии искусственного (электрические импульсы) и естественного (движение) возбуждения мышцы в двигательных актах пациента. Таким образом, исследуемый метод совмещает в себе основные направления двигательной реабилитации: кинези-, физиотерапию и функциональное ортезирование.

Электроды накладываются на мышцы нижней конечности в зависимости от поставленной задачи и выбора зоны стимуляции. После наложения электродов на пациента надевается ЭКС, устанавливается датчик контакта с опорой. Затем проводится обучение пациента.

Предварительное практическое одновременное использование электростимуляции и ЭКС на пациентах показало повышение эффективности их обучения. Пациент чувствовал дополнительную устойчивость и уверенность, ходьба становилась более четкой и ритмичной.

Использование встроенной в ЭКС программируемой стимуляции открывает новые возможности для лечения пациентов с выраженными двигательными нарушениями, у которых применение электростимуляции в ходьбе невозможно или затруднено.

кевич, Н. Н. Вовк, О. А. Горбунов // Літопис травматології та ортопедії. -2011.-(21-22) № 1-2.-С. 306.

3. Осадчий Є. О. Особенности создания информационной-трансформенной технологии для проведения кинезотерапии у больных с опорно-двигательными нарушениями / Осадчий Є. О., Горбунов О. А., Лаута А. // Матеріали щорічної наук.-техн. школи-семінару: Біологічна і медична інформатика та кібернетика. - К. : ФМШ Жукин, 21-24 черв. 2011 р. - ISBN 978-966-02-6046-7;3, [б. в.]. - 103 с. 